http://revistaseletronicas.pucrs.br/ojs/index.php/aviation

doi): http://dx.doi.org/10.15448/2179-703X.2014.1.17131

\title{
Leadership approaches in multi-cultural aviation environments
}

\section{Abordagem de liderança em ambientes multiculturais da indústria da aviação}

\author{
Jose Felix de Brito Neto ${ }^{1}$ \\ Professor do Colégio de Aeronáutica e Diretor de Design e Produção de Cursos do Departamento de Design e Desenvolvimento de Instrução \\ na Embry-Riddle Aeronautical University - Worldwide Campus, Daytona Beach, FL, Estados Unidos.
}

Trabalho realizado na Embry-Riddle Aeronautical University, Daytona Beach, FL, Estados Unidos.

\begin{abstract}
In the last few decades, the world has witnessed a phenomenon called globalization, which has shortened distances and transformed cultural contexts. The aviation industry has been part of this phenomenon as it has helped create truly global and multi-cultural workforces. Multi-cultural work environments such as the aviation industry require specific leadership approaches in order to accommodate the needs of their culturally diverse workforce. This paper is aimed at the thorough analysis of leadership approaches in multi-cultural aviation environments. Through a literature review, this paper discusses key concepts of culture and leadership as well as the ideas supporting the transformational leadership theory and the positive leadership theory, which have significant and everlasting impact in workforces. It proposes different approaches to successfully and effectively lead multi-cultural aviation workforces.
\end{abstract}

KEYWORDS: Leadership; culture; aviation

\section{RESUMO}

Nas últimas décadas, o mundo tem testemunhado um fenômeno chamado globalização, que tem encurtado distâncias e transformado contextos culturais. A indústria da aviação tem sido parte desse fenômeno por ter ajudado a criar mãos de obra verdadeiramente globais e multiculturais. Ambientes de trabalho multiculturais como o da indústria da aviação requer específicas abordagens de liderança para poder acomodar as necessidades das suas mãos de obra multiculturais. Este artigo tem como objetivo a análise minuciosa de abordagens de liderança em ambientes de trabalho multiculturais dentro da indústria de aviação. Através da revisão da literatura, este artigo discute conceitos-chave a respeito de cultura e liderança como também de ideias que apoiam a teoria da liderança transformacional e a teoria da liderança positiva. $O$ artigo propõe diferentes abordagens para a liderança bem-sucedida e efetiva de mãos de obra multiculturais na indústria da aviação.

PALAVRAS-CHAVE: Liderança; cultura; aviação

Pontifical Catholic University of Rio Grande do Sul Porto Alegre, RS, Brazil

Editor

Thaís Russomano

Microgravity Center PUCRS, Brazil

Executive Editor

Rafael Reimann Baptista

Faculdade de Educação Física e Ciências do Desporto, PUCRS, Brazil

e-ISSN: 2179-703X
Corresponding Author:

Jose Felix de Brito Neto

debritoj@erau.edu

Received: August 26, 2013

Accepted: November 13, 2014

(c) 2014 EDIPUCRS 


\section{Introduction}

The world is not the same. It is a work in progress, an organism in constant evolution, although some might wonder whether the word 'evolution' is really appropriate in this case. Throughout the years, distances have been shortened, frontiers have been reached, lands have been explored, and cultural contexts have been affected. All these milestones have culminated in a phenomenon called globalization, through which people from different countries and backgrounds attempt to coexist by sharing values, beliefs, and preferences.

Globalization has also changed organizations and the ways workforces are led and managed. Leadership approaches have mutated and adapted according to new realities in a wide array of industries. That is the case of the aviation and aerospace industry, which is formed by a culturally diverse workforce. Due to geographical and demographic limitations, some international airlines have selected and hired individuals from all corners of the planet, forming a truly global work environment. This global environment requires leaders who are equipped with the adequate knowledge, skills and attitude to effectively manage such a diverse workforce.

A number of leadership theories have been developed to assist leaders in their attempt to effectively perform in multi-cultural environments. The transformational leadership theory and the positive leadership theory are two examples of leadership theories supporting this evolution in human resource management. Both theories are focused on the fostering of highly supportive and motivational work environments, where leaders are a constant source of inspiration and the followers are given the chance to actively perform in the decision making process regardless of their cultural background.

This paper is aimed at analyzing leadership practices in multi-cultural work environments with focus on the aviation and aerospace industry. It proposes a review of the aforementioned leadership theories and the influence of their application in culturally diverse work environments.

\section{Leadership: Definition}

A wide array of studies has been conducted to analyze and conceptualize what has been universally understood as leadership. Whetten and Cameron (2011) provided a basic definition of this term by stating that leadership is formed by the actions individuals take under conditions of change. Whetten and Cameron's study about the intricacies of human resource development attempted to draw a comparison between leadership and management (2011). While management was usually associated with the status quo and steadiness, the foundation of leadership was characterized by changes happening in the environment and setting new directions in order to cope with these changes.

Throughout the years, systematic definitions of leadership came to the fore. The term leadership was coined as "the ability of an individual to influence, motivate, and enable others to contribute toward the effectiveness and success of the organizations of which they are members" (House, Hanges, Javidan, Dorfman, Gupta, and Globe Associates as cited in Dickson, Castaño, Magomaeva, and Den Hartog, 2012, p. 486). Dickson et al. (2012) also considered the idea of leadership being a process by which an individual enlisted the aid and support of other individuals in order to accomplish a certain task.

Definitions of the term leadership abound. Nevertheless, the sole existence of this ability or process is dependent on how leaders are perceived by other individuals (Ensari and MURPHY, 2003). Therefore, the relevance of leadership resides in the presence of leaders and followers alike. According to Ensari and Murphy (2003), the extent to which an individual is perceived as a leader by his or her reports in work environments has direct influence on the reports' acceptance of organizational decisions and policies as well as their organizational commitment.

Moreover, apart from the relationship between leader and follower, leadership is also defined by the styles and types of behaviors adopted by leaders. According to Wendt, Euwema, and Hetty van Emmerik (2009), there are two main types of leadership behaviors: directive leadership and supportive leadership. Directive leadership is in essence a taskoriented behavior; directive leaders tend to control discussions, dominate interaction and give directions toward task completion in a truly micromanagement style. This type of behavior results in followers being given a dependent and secondary role, which gives center stage for leaders to perform (Wendt et al., 2009).

Conversely, supportive leadership is intrinsically centered on the satisfaction of subordinates' needs and preferences, harmonic working relations, and positive feedback. All these factors culminate on a friendly and supportive climate in work environments. Through this leadership style, followers have active roles in the decision-making process and adopt cohesive behavior regarding task completion and personal communication (Wendt et al., 2009). 


\section{Culture: Definition}

The conceptualization of the word culture is a multi-faceted process that results in a myriad of meanings. According to Dickson et al. (2012), the word culture usually refers to groups of individuals within a society or groups of things that differentiate one society from another. Herskovits (as cited in Dickson et al, 2012, p. 483) described culture as "an agreement that members of the society come to and something that new members can learn; culture specifies individuals' natural and societal settings such as thought patterns, government structure and values of possessions."

In their study about culture value dimensions, Ergeneli, Gohar, and Temirbekova (2007, p. 707) defined culture "as shared motives, values, beliefs, identities and interpretations or meanings of significant events that result from the common experiences of the members of a society." They went on to add that the word culture is generally applied to societies that constitute a social system presenting the highest level of self-sufficiency in regards to its surrounding environment.

A variety of studies have cited Hofstede's culture value dimensions (Dickson et al., 2012; Engeneli et al., 2007; Ensari and Murphy, 2003; Wang et al., 2012; Wendt et al., 2008). According to Engerneli et al. (2007), Hofstede developed five culture value dimensions within societies that have substantial face validity and that are directly related to certain aspects of management. The five culture value dimensions are: power distance, uncertainty avoidance, individualismcollectivism, masculinity and femininity, and, lastly, long-term and short-term orientations.

Power distance refers to the inequality (represented by distance) of power among institutions, organizations and individuals. This value is related to the attempts of the more powerful to maintain or extend distance and the attempts of the less powerful to reduce it. Uncertainty avoidance is directly related to the level of tolerance presented by individuals towards ambiguity and unstructured situations. According to Ergeneli et al. (2007), clear procedures, well-defined and wellcommunicated strategies, and effectively understood rules are powerful tools against uncertainty avoidance.

Individualism-collectivism refers primarily to the tendency of individuals to cluster into primary groups. It is also linked to the degree to which individuals are expected to take care of themselves or maintain a certain level of integration in groups (Ergeneli et al., 2007). Individualism and collectivism are the opposite ends of human integration. According to Wendt et al. (2009), the individualism-collectivism dimension is the most popular of the cultural dimensions as it has been studied extensively in organizational research.

The fourth dimension is centered on the dichotomy between masculinity and femininity. According to Ergeneli et al. (2007), the masculinity dimension presents the assumption that dominant values such as assertiveness, heroism and achievement are fundamentally masculine, while the feminine dimension revolves around values such as high quality of life, long lasting relationships, and care towards individuals.

Long-term and short-term orientations are the last of the culture value dimensions developed by Hofstede (Ergeneli et al., 2007). Individuals that have a longterm orientation tend to accept deferred gratification of needs; their relationships are ordered by status, and people (instead of law) constitute their government. Conversely, individuals that drift toward short-term orientation expect quick results and rewards, pursue personal steadiness and stability, and treasure leisure time.

These dimensions are instrumental in the general understanding about the intricacies of cultural contexts, which are expressed by values and beliefs individuals have in common. These dimensions offer a canvas on which human relations, especially within organizations, are drawn. The analysis of leadership is, therefore, greatly enhanced by the clear description of these dimensions.

\section{Leadership in Multi-cultural Aviation Environments}

Despite the financial upheavals that have shaken the world to the core, globalization continues to reach further and implode more barriers between systems, extinguish borders between countries, and require leaders to operate in truly global environments (Youssef and Luthans, 2012). Being a truly global system, the aviation and aerospace industry requires the input of a culturally diverse workforce to effectively operate within its numerous supporting subsystems.

Due to geographical and demographic limitations, some organizations within the aviation industry, mainly airlines, have launched worldwide recruitment strategies to fill their job positions in a wide array of departments, mainly in service delivery. Emirates Airline, Qatar Airways, and Singapore Airlines are examples of organizations that employ individuals from all corners of the world given the limited human resources in these airlines' home countries (United Arab Emirates, Qatar and Singapore, respectively) (Emirates Group Careers, 2014; Qatar Airways, 2014; Singapore Airlines, 2014). Their headquarters are now 
multi-cultural environments carrying many flags and accommodating a variety of citizenships and cultural backgrounds.

In light of these circumstances, cultural factors within global environments have exercised direct influence on the basic process supporting leadership relations. Organizations within the aviation and aerospace industry have become examples of work environments that demand the guidance and support of leaders who are able to effectively adapt the management theories that have been developed in the Western context (Wang et al., 2012) and efficiently perform across different cultures (Ergeneli et al., 2007).

Having said that, a thorough analysis of the ideas behind leadership now requires an understanding on how leaders perform and how followers process information in distinguished cultural contexts (Ensari and Murphy, 2003). Many studies about leadership practices have mentioned the results of the Global Leadership and Organizational Behavior Effectiveness (GLOBE) project (Dickson et al., 2012; Ensari and Murphy, 2003; Ergeneli et al., 2007; Wang et al., 2012; Wendt et at. 2009; Youssef and Luthans, 2012). According to Wang et al. (2012, p. 571), GLOBE is "an influential effort that explores the impact of cultural values on leadership effectiveness in 62 countries" with the purpose of developing an empirically based study about cross-cultural leadership.

The studies developed by GLOBE were based on nine different cultural dimensions: performance orientation, future orientation, assertiveness, power distance, human orientation, institutional collectivism, uncertainty avoidance, and gender egalitarianism. GLOBE and many other studies have attempted to understand how leadership is exercised across different cultures. According to Dickson et al. (2012), these studies have fundamentally attempted to identify leadership characteristics that are universally applicable and those that pertain to specific countries.

In his cross-cultural studies, Lonner (as cited in Dickson et al., 2012) separated universal values into three categories: simple universals, variform universals, and functional universals. Simple universals are those values and types of behavior that are applicable to all countries and cultures. An example of the simple universal values is the human need to belong and communicate. Variform universals are those values that refer to human need to belong and communicate in a different way. Lastly, functional universals are those values that are linked to the stability of the intricacies of relationships that are valid across all cultures.

According to the results of the GLOBE studies, universal characteristics that exercise positive influence on job satisfaction and effective leadership are charisma, communication of vision, and desire to change the status quo. Additionally, universally effective and accepted leaders are inspirational, visionary, motivational, dynamic, good communicators, decisive, intelligent, and win-win problem solvers. They are confidencebuilding, team-building, and excellenceoriented individuals (Dickson et al., 2012).

Conversely, leaders that tend to become loners, ruthless, irritable and dictatorial are universally rejected by followers (Dickson et al., 2012). Universally rejected leadership characteristics tend to be negatively evaluated by followers, which results in damaging effects on group dynamics and increasing group resistance to work further (Wendt et al., 2009).

In the opposite side of this cross-cultural spectrum, there is a host of characteristics that are known for being culturally contingent and for pertaining to specific countries. According to Dickson et al. (2012), leaders that are risk taking, ambitious, self-sacrificial, sincere, sensitive, compassionate, willful, and enthusiastic tend to be accepted in some countries, but not in others.

Nonetheless, the acceptance and effectiveness of leadership performances is directly contingent to the alignment and congruence of leadership behavior with the norms of the culture in which the leaders perform. Whether charismatic or a loner, ruthless or supportive, leaders must accomplish cohesiveness in management in order to reach effectiveness in their performance.

Given these circumstances, a number of leadership theories have been instrumental in supporting and guiding individuals in multi-cultural environments, such as transformational leadership theory and positive leadership theory. These theories, which Ergeneli et al. (2007, p. 704) called "neocharismatic theories", are built around leader behavior and facilitate the understanding of truly global leadership.

\section{Transformational Leadership Theory}

The transformational leadership theory, which is fairly new within the array of leadership theories, has the primary function of expanding the role of charismatic leaders who exercise a high level of emotional appeal and power over their followers. This leadership theory acknowledges the relevance of symbolic, emotional and distinctly motivating behaviors and attitude that inherently exercise allure to followers' minds and leads to exceptional results in the work environment (Ergeneli et al., 2007).

Unlike the transactional leadership theory, which attempts to fulfill the needs of the followers by emphasizing the exercise of exchange, the 
transformational leadership theory motivates others to accomplish more than they are expected to accomplish. Transformational leaders adopt intellectual stimulation, which leads followers to question their own beliefs, values and expectations and to rethink ideas that have never been questioned before (Ergeneli et al., 2007).

Moreover, the transformational leadership theory applies individualized consideration, through which leaders exercise significant individual attention to each of their followers. By applying individualized consideration, leaders delegate authority to their followers while coaching them and treating them equally (Ergeneli et al., 2007).

In work environments where the transformational leadership theory is extensively applied, the workforce is composed by highly knowledgeable employees who make use of the envisioning and empowering techniques provided by their leaders. This sharing of vision and power leads to common technical imperatives, industrial logic, and knowledge on global technologies, which greatly facilitate management practices in multicultural and global work environments (Ergeneli et al., 2007).

Studies developed by Kouzes and Posner (as cited in Ergeneli et al., 2007) have focused on transformational leadership cases and led to a compilation of best practices adopted by transformational leaders. Transformational leaders usually challenge the existing process by developing strategies to change the status quo; inspiring a shared vision by envisioning the future and creating an ideal image of what the organization may become; enabling others to act by encouraging collaboration and assembling spirited teams; modelling the way by establishing principles that guide individual behavior; and encouraging good behavior by celebrating accomplishments with rewards (Ergeneli et al., 2007).

In spite of being heralded as universally adopted, the transformational leadership theory has undergone substantial analysis. Some studies revealed that this theory may not be equally and effectively applicable to all cultures, which leads to believe that this leadership theory lacks a truly global perspective (Youssef and Luthans, 2012).

\section{Positive Leadership Theory}

Similarly to the transformational leadership theory, the positive leadership theory was created to provide guidance in times of globalization and financial upheavals that have distressed the world in the past few years. Effective leadership under these circumstances has demanded comprehensive theoretical frameworks emphasizing cultural differences that global leaders lack. Positive leadership theory goes beyond the transformation leadership theory as it establishes common ground by leveraging diversity both locally and globally (Youssef and Luthans, 2012).

In their study about leadership in global environments, Youssef and Luthans (2012) listed the advantages of positivity. In fact, the term has been studied extensively as it elevates process and outcomes. It also precludes negativity, neutrality, complacency, resistance to change, and prolongation of the status quo. Moreover, positivity is closely related to human flourishing, which enables individuals to perform an optimal range.

The positive leadership theory is closely connected to the study of the Positive Organizational Behavior (POB), which is focused on positively oriented human resource strengths and psychological abilities that can be measured and managed for performance improvement. $\mathrm{POB}$ is based on four psychological resources: (a) hope, which is a positive motivational condition; (b) efficacy, which is the individual ability to execute specific actions within given contexts and criteria; (c) resilience, which is the individual ability to recover from adversity, conflict and failure; and, lastly, (d) optimism, which is an overall positive expectancy (Youssef and Luthans, 2012).

The conceptualization of the positive leadership theory includes the systematic manifestation of leadership traits and processes that reinforces the strengths and capabilities of leaders and followers alike. It extinguishes cultural borders and offers a broad and positive perspective (Youssef and Luthans, 2012).

The positive leadership theory is closely connected to emerging leadership theories such as ethical leadership, spiritual leadership, and authentic leadership. Ethical leadership aims to elevate processes, behaviors and performance outcomes. Supported across cultures, ethical leadership focuses on integrity, altruism, collective motivation and encouragement. Spiritual leadership places emphasis on motivation through a sense of membership or community between leaders and followers. It is based on kindness, forgiveness, empathy, honesty and humility. Authentic leadership fosters a highly supportive organizational climate; this climate is reached when leaders share their own personal experiences, thoughts, beliefs and preferences. It is centered on self-awareness, transparency and internalized moral perspective (Youssef and Luthans, 2012).

Positive leaders tend to mitigate challengers of any kind in work environments, especially when it comes to physical and psychological distance and cultural differences. They adopt a systematic and 
integrated approach considering their own strengths and capabilities as well as those of their followers and of their organizations. Moreover, they facilitate the development of a global mindset and intercultural sensitivity among their followers.

Given the multi-cultural environments that have been developed within the workforce of a number of international airlines, the adoption of transformational or positive leadership theories has become paramount. In order to effectively guide and lead followers in the highly competitive environment that airlines operate, leaders must follow the principles established by these theories. The adoption of these theories will result in nothing but empowered, highly motivated, cohesive and efficient multi-cultural workforces.

\section{Final Considerations}

The aviation and aerospace industry is a large system formed by highly active, functional and integrated subsystems. The industry is deemed as one of the few truly global environments, given the scope and range of operatives it encompasses. It is deeply contingent to the financial swings the world has experienced along the years. It is also a facilitator and a fruit of globalization, as it transports passengers to the most remote spots in the planet and attracts and employs individuals from a variety of cultural backgrounds.

Given these circumstances, in order to manage and lead workforces with a wide array of cultural backgrounds, the aviation and aerospace industry demands leaders that are able to effectively navigate across cultures by inspiring, motivating and bringing the best of their employees regardless of the country they come from.

A thorough understanding of the intricacies surrounding the relationship between culture and leadership facilitates the effectiveness of leadership approaches in multi-cultural environments. Both words, culture and leadership, aggregate many concepts and are based on numerous principles. Their true meanings are just as diverse as the number of countries in the world.

Understanding how leaders and followers operate based on their cultural backgrounds is instrumental in the enhancement of leadership performance. Cultural value dimensions and leadership theories are valuable tools to reach effectiveness in leadership. In regards to the aviation and aerospace industry, which is quite a regimented, multi-faceted and extremely diverse system, the adoption of either the transformational leadership theory or the positive leadership theory immensely facilitate the operatives of organizations that constitute such a competitive and fragile environment.

\section{References}

DICKSON, W. M.; CASTAÑO, N.; MAGOMAEVA, A.; DEN HARTOG, D. N. Conceptualizing leadership across cultures. In: Journal of World Business, v. 47, n. 4, p. 483-492, out. 2012. Disponivel em: <http://www.sciencedirect.com/science/article/ pii/S109095161200003X > . Acesso em: 20 jan. 2014.

EMIRATES GROUP CAREERS. Explore our careers: Cabin crew. Emirates Group Careers. Disponivel em: <http:/ emiratesgroupcareers.com/english/Careers_Overview/cabin crew/default.aspx >. Acesso em: 05 mar. $20 \overline{1} 4$.

ENGENELI, A.; GOHAR, R.; TEMIRBEKOVA, Z. Transformational leadership: Its relationship to culture value dimensions. In: International Journal of Intercultural Relations, v. 31, n. 6, p. 703-724, nov. 2007. Disponivel em: <http://www. sciencedirect.com/science/article/pii/S0147176707000430>. Acesso em: 21 jan. 2014.

ENSARI, N.; MURPHY, S. E. Cross-cultural variations in leadership perceptions and attribution of charisma to the leader. In: Organizational Behavior and Human Decision Processes, v. 92, n. 1-2, set.-nov. 2003. Disponivel em: <http://www. sciencedirect.com/science/article/pii/S0749597803000669>. Acesso em: 08 jan. 2014.

QATAR AIRWAYS. News and events. Qatar Airways. Disponivel em: <http://careers.qatarairways.com/qatarairways/ News.aspx >. Acesso em: 05 mar. 2014.

SINGAPORE AIRLINES. Careers: Cabin crew appointments Singapore Airlines. Disponivel em: < http://www.singaporeair. com/en UK/careers/cabin-crew-appointments/>. Acesso em: 05 mar. 2014 .

WANG, H.; WALDMAN, D. A.; ZHANG, H. Strategic leadership across cultures: Current findings and future research directions. In: Journal of World Business, v. 47, n. 5, p. 571-580, out. 2012. Disponivel em: <http://www.sciencedirect.com/ science/journal/10909516/47 >. Acesso em: 10 jan. 2014.

WENDT, H.; EUWEMA, M.; HETTY VAN EMMERIK, I. J. Leadership and team cohesiveness across cultures. In: The Leadership Quarterly, v. 20, n. 3, p. 358-370, june 2009. Disponivel em: <http://www.sciencedirect.com/science/article/ pii/S1048984309000812 >. Acesso em: 09 jan. 2014.

WHETTEN, D. A.; CAMERON, K. S. Developing management skills. 8. ed. Upper Saddle River, NJ: Prentice Hall, 2011. 774p. YOUSSEF, C. M.; LUTHANS, F. Positive global leadership. In: Journal of World Business, v. 47, n. 4, p. 539-547, out. 2012. Disponivel em: < http://www.sciencedirect.com/science/article/ pii/S1090951612000089>. Acesso em: 15 jan. 2014.

\footnotetext{
Corresponding Author:

Jose Felix de Brito Neto

Embry-Riddle Aeronautical University - Worldwide

600 South Clyde Morris Boulevard

Daytona Beach, FL 32801

Tel.: (+1 407) 247- 3983

<debritoj@erau.edu>
} 